\title{
Effects of the polypropylene mesh implanted through inguinotomy in the spermatic funiculus, epididium and testis of $\operatorname{dogs}^{1}$
}

\author{
Efeitos da tela de polipropileno implantada por inguinotomia no funículo espermático, \\ epidídimo e testículo de cães
}

\author{
Alberto Goldenberg ${ }^{2}$, Joaquim Ferreira de Paula ${ }^{3}$ \\ 1. Study conducted at the Veterinarian School Hospital (HVE) of the Faculty of Veterinarian Medicine (FMV) and at the Pathology \\ Laboratory of the Faculty of Medicine (FM) of the Educational Foundation D. André Arcoverde (FAA), Valença, RJ and at the Federal \\ University of São Paulo - Escola Paulista de Medicina (EPM). \\ 2. Adjunct Professor - Department of Surgical Gastroenterology of UNIFESP - EPM. \\ 3. Assistant Professor - Disciplines: Surgical Technique/Experimental Surgery and Clinical Surgery - FM - FAA.
}

\begin{abstract}
Purpose: To investigate the effects of polypropylene mesh, implanted by inguinotomy, in the spermatic funiculus, epididium and testis of dogs. Methods: Eighteen dogs were considered (12-23 Kg), separated in three groups. Group A (n=7): left side (with mesh) versus right side (without mesh); Group B ( $n=7)$ : left side (without mesh) versus right side (with mesh) and Group C ( $n=4)$ : without any surgical manipulation (control group). After being observed for 60 days, the animals were subjected to bilateral removal of the spermatic funiculus, epididium and testis that were submitted to histological analysis. During the re-operation, a macroscopic evaluation was performed. Results: On the mesh side, we noted 100\% of mesh adherence to the posterior wall of the inguinal canal, as well as the adherence of the spermatic funiculus to the mesh. A congestion of the pampiniform plexus was noted in three animals. Chronic inflammation reaction and foreign body reaction in the spermatic funiculus was observed in $100 \%$ of the animals. On the side that did not carry a mesh, chronic inflammatory reaction was observed in $71 \%$ of the animals. All the animals presented chronic inflammatory reaction in the deferent duct in the mesh side and in eleven animals in the side without the mesh. These alterations were not found in Group C. There was a considerable statistical reduction in the average difference of the diameter of the lumen of the deferent duct in the mesh side. In the epididium and testis, macro and microscopic alterations were not significant, although one animal presented a marked reduction of spermatogenesis on the mesh side. Conclusion: The polypropylene mesh, when in contact with the spermatic funiculus of dogs, causes a more intense chronic inflammatory reaction and a significant reduction in the diameter of the lumen of the deferent duct.
\end{abstract}

Key words: Hernia, Inguinal. Surgical Mesh. Polypropylenes. Dogs.

\section{RESUMO}

Objetivo: Investigar os efeitos da tela de polipropileno implantada por inguinotomia no funículo espermático, epidídimo e testículo de cães. Métodos: Foram utilizados 18 cães (12-23 Kg) distribuídos em três grupos: Grupo A (n=7): lado esquerdo (com tela) e lado direito (sem tela); Grupo B (n=7): lado esquerdo (sem tela) e lado direito (com tela) e Grupo C (n=4): sem manipulação cirúrgica (Grupo controle). Após 60 dias, os animais foram submetidos a remoção bilateral do funículo espermático, do epidídimo e testículos e encaminhados para estudo histológico. Durante a re-operação foi realizada avaliação macroscópica. Resultados: No lado com tela observou-se 100\% de aderência à parede posterior do canal inguinal, assim como no funículo espermático. Observou-se congestão do plexo pampiniforme em três animais. Verificouse reação inflamatória crônica e de corpo estranho em $100 \%$ dos funículos espermáticos. Do lado que não recebeu a tela observou-se reação inflamatória crônica em $71 \%$ dos animais. Todos os animais apresentaram reação inflamatória crônica no ducto deferente do lado com tela e em 11 animais no lado sem tela. Essas alterações não foram encontradas no Grupo C. Ocorreu uma redução estatisticamente significante na diferença de diâmetro do lúmen do ducto deferente no lado com tela. No epidídimo e testículo, as alterações macro e microscópicas não foram significantes, porém um animal apresentou redução acentuada da espermatogênese no lado com tela. Conclusão: A tela de polipropileno em contato com o funículo espermático de cães causa reação inflamatória crônica intensa e redução significante do diâmetro do lúmen do ducto deferente. Descritores: Hérnia, Inguinal. Tela Cirúrgica. Polipropileno. Cães. 


\section{Introduction}

The treatment of inguinal hernias is eminently surgical and mesh repair, considered free of tension (Lichtenstein), became a choice method for the majority of inguinal hernias ${ }^{1}$, because the techniques that utilize autologous tissue (Bassini, Mc Vay, Shoudice, etc.) may produce tension caused by the repair and may result in recurrence ${ }^{2}$. Although the history of the development of synthetic prostheses, registers that many materials have been used, nowadays, polypropylene prosthesis is the most commonly used today ${ }^{3}$. All hernioplasty techniques may present postoperative occurrences related to the scrotum and testis, such as hematomas, atrophy, sterility, tumefaction, ecchymosis and hydrocele ${ }^{4}$. There are reports specifically related to the mesh correction of inguinal hernias, showing that there is a relationship with spermatogenesis reduction ${ }^{5}$ and infertility ${ }^{6,7}$. The increase of hernia correction by means of prosthesis and the interest in fertility latter in life ${ }^{2}$, added to the fact that the mesh (foreign body) provokes a strong fibroblastic reaction in the cicatrisation process of the posterior wall of the inguinal canal ${ }^{2,3}$ whose effects on the structures and function of the spermatic funiculus, epididium and testis are well known, motivated us to go on studying this matter. The objective of this work is to evaluate the effects of the polypropylene mesh, implanted by inguinotomy, on the spermatic funiculus, epididium and testis of dogs.

\section{Methods}

\section{Sample}

Eighteen mongrel male adult dogs, apparently healthy, weighting between 12 and $23 \mathrm{~kg}$ were considered. They were housed in the Animal House of the Veterinarian School Hospital (HVE) of the Faculty of Veterinarian Medicine of Valença. The study was approved by The Ethics Committee of the HVE and by the Ethics Committee of the Federal University of São Paulo - Escola Paulista de Medicina. The handling of the dogs followed the ethical principles of the Brazilian College of Animal Experimentation.

\section{Procedures}

The animals were divided in three groups: Group A $(n=7)$, Group B $(n=7)$ and Group C $(n=4)$. We implanted the mesh on the left side of the animals of Group A and on the right side on the animals of Group B. The contra-lateral side of each animal was dissected, but did not receive the mesh. Animals in Group C did not undergo any surgical manipulation and acted as control group. We used intravenous $0,2 \mathrm{mg} / \mathrm{kg}$ acepromazine (Acepran ${ }^{\circledR} 1 \%$ ) in preanesthesia, thirty minutes before the procedure, as well as intramuscular antibiotic prophylaxis with Agrovet $^{\circledR} 5.000 .000$ (benzylpenicillin - 375.000 U.I., potassium benzylpenicillin -125.000 U.I. and streptomycin - $200 \mathrm{mg}$ ). In anesthesia we used $25 \%$ sodium thiopental, dosage of $12,5 \mathrm{mg} / \mathrm{kg}$, endovenously. During the surgical procedure, anesthesia was maintained with Halothane. We dissected the spermatic funiculus through oblique inguinotomy, $4 \mathrm{~cm}$ long, $2 \mathrm{~cm}$ above the inguinal ligament, and inserted the plane polypropylene prosthesis (ETHICON, INC - EUA, Lot No QKE142), 4 x 3 cm, with simple stitches of nylon 3-0 thread $\left(\mathrm{TECHNOFIO}^{\circledR}\right.$ ) on the aponeurotic tissue, on the pubis (one stitch), on the internal oblique muscle (two stitches) and on the inguinal ligament (three stitches). After the spermatic funiculus was accommodated, surrounded by the opening of the mesh, without constriction, we approximated the inferior sides of the opening with the same thread and fixed them to the inguinal ligament (Figure 1).

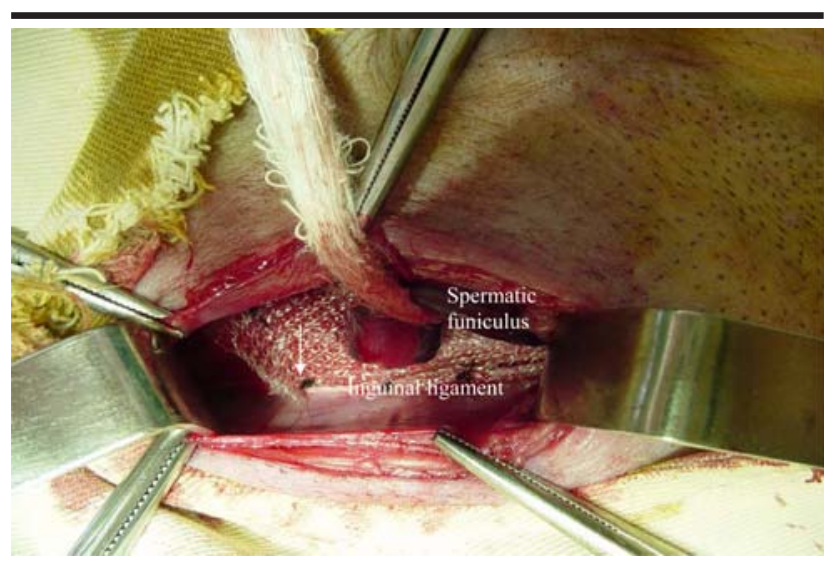

FIGURE 1 - Fixed mesh on the inguinal ligament and the spermatic funiculus, surrounded by the approximation of the edges of the opening of the mesh (arrow). Animal IX - Right side.

Next, with the same kind of stitch and thread, we sutured the aponeurosis of the external oblique muscle, the subcutaneous layer and the skin. On the contra-lateral side (without mesh), dissection and sutures were similar to the ones on the side with implanted mesh. In group $C$, the spermatic funiculus, the epididium and the testis were removed, concomitantly with a macroscopic evaluation, including the measurement of the testis with a Sanny Starrett ${ }^{\circledR}$ adipometer No 3025-481. After the removal of the anatomical pieces, the animals were subjected to euthanasia with the endovenous administration of $40 \mathrm{ml}$ of $10 \%$ magnesium sulfate. Animals in groups A and B were under observation for 60 days with daily evaluation of food, physiological functions and surgery wound control. Next, the animals were re-operated following the same procedures for group C.

\section{Macroscopic evaluation}

During surgery for the removal of the spermatic funiculus, epididium and testis, our attention was focused on the possible presence of morphological alterations in these structures. We evaluated the presence of adherence to the posterior wall of the inguinal canal with the mesh and with the spermatic funiculus, the presence of congestion of the pampiniform plexus and the size of the testis.

\section{Microscopic evaluation}

The spermatic funiculus, the epididium and the testis were sent to the Pathology Department of the Faculty of 
Medicine of Valença, including a testis sample for fixation in Bouin's solution. The histological glass slides, 25 to 1000 times magnified were evaluated with micrometric rule and ocular. They were stained with Hematoxylin and Eosin and Gomori Tricomium, prepared according to Michalany's procedures $^{8}$. We evaluated the presence of acute/chronic inflammatory reaction, classified according to a qualitative scale proposed by Fitzgibbons et al. ${ }^{9}$ :

No inflammation: absence of fibrosis or giant cells;

Light inflammation: dense fibrosis with few giant cells;

Moderate inflammation: fibrosis with few polymorphonuclear leukocytes and giant cells; Intense inflammation: loose fibrosis with a great number of polymorphonuclear leukocytes and giant cells.
We measured the diameter of the lumen of the deferent duct at the proximal third, from the epididium duct to the level of the body and of the seminiferous tubes, in transversal sections, using the conversion factors indicated in Table 1. The diameter of the lumen of the epididium duct and seminiferous tubes were obtained from the average of six measuring sessions in different microscopic fields. The diameter of the lumen of the deferent duct was obtained from a sole microscopic field. Using the average difference of the diameters for each animal, the mesh sides were compared with the sides without mesh. In the epididium, at the level of the body, we made a quantitative evaluation of the spermatozoids and in the testis we evaluated the Leydig, Sertoli and spermatogenic cells. Data from the group control animals acted as the histological normalcy basis for groups $\mathrm{A}$ and $\mathrm{B}$, and were not used in the statistical analysis.

TABLE 1 - List of magnifying lenses value and of the corresponding conversion factors used in the measurement of the diameters.

\begin{tabular}{cccc}
\hline Ocular/Ruler & Objective & Number of marks in the ruler & Conversion Factor \\
\hline 10 & 2,5 & $\mathrm{X}$ & 0,047619 \\
10 & 10 & $\mathrm{X}$ & 0,0125 \\
10 & 25 & $\mathrm{X}$ & 0,005 \\
10 & 40 & $\mathrm{X}$ & 0,003 \\
10 & 100 & $\mathrm{X}$ & 0,0012195 \\
\hline
\end{tabular}

$\mathrm{X}$ obtained value from the superposition of the ruler at the lumen of the structure to be measured.

\section{Statistical analysis}

A statistical analysis was conducted taking in to consideration the variables involved. In all tests, the level of rejection of the nullity hypothesis was fixed in 0,05 or $5 \%$ :

- for the numeric variables we used Student's paired $\mathrm{t}$ test ${ }^{10}$.

- for the categorical variables we used the signal test ${ }^{11}$.

\section{Results}

\section{Macroscopic aspects}

In re-operation, $100 \%$ of the animals' side with implanted prosthesis presented marked adherence of the mesh to the posterior wall of the inguinal canal and moderate adherence between the spermatic funiculus and the mesh. In the contra-lateral side (without mesh) of these animals and control group, the presence of adherence was not noted. Three animals ( 1 in group A and 2 in group B) presented congestion of the pampiniform plexus and one of these animals also presented hydrocele on the mesh side. The average size of the testis on the group with mesh, group without mesh and control group was respectively $3,8 \mathrm{~cm}$, $3,8 \mathrm{~cm}$ and $3,7 \mathrm{~cm}$.

\section{Microscopic aspects}

The spermatic funiculus of the animals of group A and $\mathrm{B}$, on the mesh implanted side (near the deep inguinal ring) presented chronic inflammatory reaction and foreign body reaction in $100 \%$ of the cases. On the contra-lateral side of these same groups, chronic inflammatory reaction was present in 10 animals (72\%). When jointly comparing the prosthesis side with the side without prosthesis, 12 animals (86\%) presented a larger inflammatory reaction on the prosthesis side, with significant statistical difference (Table 2). Group $C$ presented no inflammatory reaction in the spermatic funiculus. Fourteen animals presented, on the prosthesis side, chronic inflammatory reaction on the deferent duct (12 light reactions and 2 moderate reactions), as shown in Figure 2. On the contra-lateral sides, 11 animals presented light chronic inflammatory reaction. In the comparative evaluation between both sides (Table 3), 50\% of the animals presented a more intense inflammatory reaction on the mesh side $(\mathrm{p}<0,063)$.

TABLE 2 - Comparative distribution of the sides with and without prosthesis, according to the evaluation of chronic inflammatory reaction in the spermatic funiculus.

\begin{tabular}{lllll}
\hline Without & \multicolumn{3}{c}{ With prosthesis } & \multirow{2}{*}{ Total } \\
\cline { 2 - 4 } prosthesis & Light & Moderate & Intense & \\
\hline Absent & 0 & $3(21 \%)$ & $1(7 \%)$ & $3(21 \%)$ \\
Light & $2(14 \%)$ & $7(50 \%)$ & $1(7 \%)$ & $11(79 \%)$ \\
Total & $2(14 \%)$ & $10(71 \%)$ & $2(14 \%)$ & $14(100 \%)$ \\
\hline
\end{tabular}

Signal test $(\mathrm{p}<0,001)$

* Statistical significance $\alpha=0,05$ 
TABLE 3 - Comparative distribution of the sides with and without prosthesis, according to the evaluation of the chronic inflammatory reaction of the deferent duct.

\begin{tabular}{llll}
\hline Without & \multicolumn{2}{c}{ With prosthesis } & \multirow{2}{*}{ Total } \\
\cline { 2 - 3 } prosthesis & Light & Moderate & \\
\hline Absent & $3(21 \%)$ & 0 & $3(21 \%)$ \\
Light & $9(64 \%)$ & $2(14 \%)$ & $11(79 \%)$ \\
Total & $12(86 \%)$ & $2(14 \%)$ & $14(100 \%)$ \\
\hline
\end{tabular}

Signal Test $(\mathrm{p}<0,063)$

*Statistical significance $\alpha=0,05$

The control group presented no inflammatory reaction. The average diameter of the lumen of the deferent duct on the mesh side, on the side without mesh and on the control group was respectively $0,32 \mathrm{~mm}, 0,35 \mathrm{~mm}$ and $0,37 \mathrm{~mm}$. There was a statistically significant reduction of the lumen of the deferent duct on the prosthesis side (Table 4). Three animals presented chronic inflammatory reaction (Group A: 1 light reaction and 1 moderate reaction; Group B: 1 light reaction) on the mesh side of the epididium and, on the contra-lateral side, only one animal presented light chronic inflammation on both sides. In the control group, one animal presented light chronic inflammatory reaction on the left side and another animal presented a micro abscess on the right side. Two animals of group A (prosthesis side) and one animal of the control group (both sides) presented spermatozoid reduction in the epididium duct. The average diameter of the lumen of the epididium duct with mesh implant, without mesh implant and control group was, respectively, 0,14 mm, $0,16 \mathrm{~mm}$ and $0,16 \mathrm{~mm}$. There was an average reduction of the diameter of the lumen of the epididium duct on the prosthesis side; however, it was not significant (Table 5).

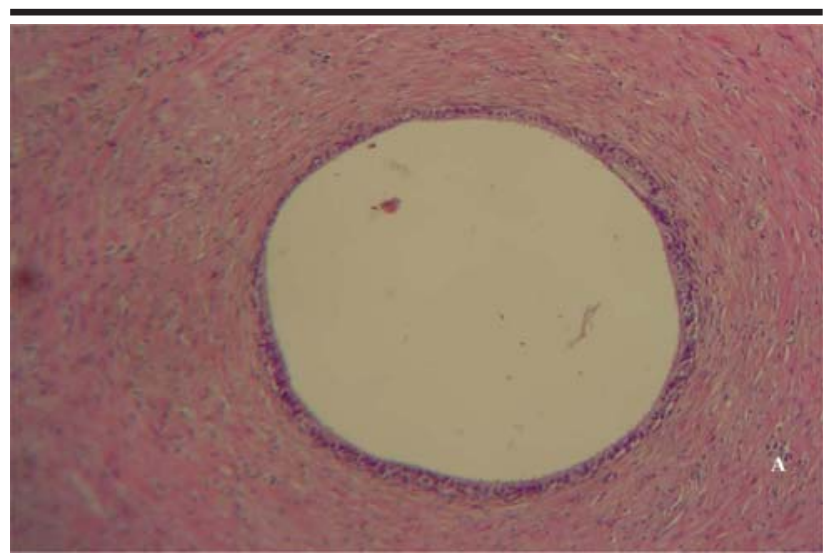

FIGURE 2 - Histological cut of the deferent duct (HE - 400x), showing light inflammatory reaction on the muscular layer (A) and the circular aspect of the mucosa. Animal VI Left side (with mesh).

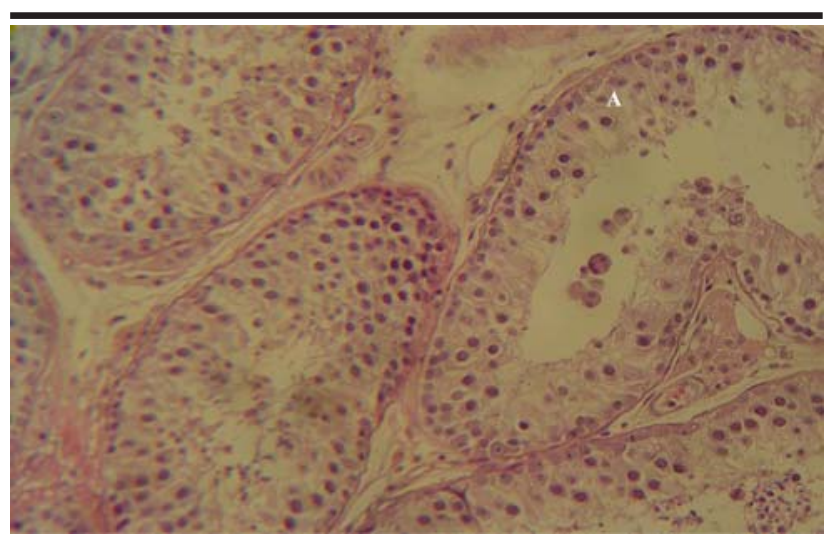

FIGURE 3 - Histological cut of the testis (HE - 400x) showing the marked reduction of spermatogenesis (A). Animal VII - Left side (with mesh).

TABLE 4 - Distribution of measurements (mm) of the diameters of the lumen of the deferent ducts, according to the sides with prosthesis and without prosthesis and control group.

\begin{tabular}{|c|c|c|c|c|c|c|}
\hline \multirow[b]{2}{*}{ Group } & \multirow{2}{*}{$\begin{array}{l}\text { With } \\
\text { prosthesis } \\
(\mathrm{n}=14)\end{array}$} & \multirow{2}{*}{$\begin{array}{l}\text { Without } \\
\text { prosthesis } \\
\quad(n=14)\end{array}$} & \multirow[b]{2}{*}{$\begin{array}{l}\text { Variation } \\
\text { (\%) }\end{array}$} & \multirow{2}{*}{$\begin{array}{c}\text { Difference } \\
\text { between sides } \\
\text { (with prosthesis - } \\
\text { without prosthesis) } \dagger\end{array}$} & \multicolumn{2}{|c|}{ Control group $(C)$} \\
\hline & & & & & $\begin{array}{c}\text { Left } \\
\text { side } \\
(n=4)\end{array}$ & $\begin{array}{l}\text { Right } \\
\text { side } \\
(n=4)\end{array}$ \\
\hline A & 0,35 & 0,41 & & $-0,06$ & 0,41 & 0,37 \\
\hline A & 0,38 & 0,35 & & 0,03 & 0,45 & 0,42 \\
\hline A & 0,31 & 0,38 & & $-0,07$ & 0,37 & 0,37 \\
\hline A & 0,42 & 0,42 & & 0 & 0,23 & 0,35 \\
\hline A & 0,32 & 0,37 & & $-0,05$ & & \\
\hline A & 0,50 & 0,48 & & 0,02 & & \\
\hline A & 0,28 & 0,37 & & $-0,09$ & & \\
\hline B & 0,22 & 0,37 & & $-0,15$ & & \\
\hline B & 0,23 & 0,23 & & 0 & & \\
\hline B & 0,35 & 0,37 & & $-0,02$ & & \\
\hline B & 0,30 & 0,30 & & 0 & & \\
\hline B & 0,23 & 0,23 & & 0 & & \\
\hline B & 0,22 & 0,38 & & $-0,16$ & & \\
\hline B & 0,33 & 0,41 & & $-0,08$ & & \\
\hline Average & 0,32 & 0,36 & $-12,4$ & $-0,045^{*}$ & & \\
\hline
\end{tabular}

† Student's test $\mathrm{t}(\mathrm{p}=0,015)$

* Statistical significance $\alpha=0,05$ 
On the prosthesis side of one dog of group A there was a light chronic inflammatory reaction of the testis involving the internal face of the albuginea tunic and in another dog a marked reduction of spermatogenesis (Figure $3)$. On the contra-lateral sides and control group no alteration was noted. Leydig and Sertoli cells were quantitatively normal in all the animals. The average of the diameters of the lumen of the seminiferous tubes on the mesh side, without mesh and control group was respectively, $77 \mu \mathrm{m}, 76 \mu \mathrm{m}$ and $78 \mu \mathrm{m}$. There was an average increase in the diameter of the lumen of the seminiferous tubes on the prosthesis side; however, it was not significant (Table 6).

TABLE 5 - Distribution of the measurements (mm) of the diameters of the lumen of the epididium ducts, according to the side with prosthesis, without prosthesis and control group.

\begin{tabular}{|c|c|c|c|c|c|c|}
\hline \multirow[b]{2}{*}{ Group } & \multirow{2}{*}{$\begin{array}{l}\text { With } \\
\text { prosthesis } \\
(\mathrm{n}=14)\end{array}$} & \multirow{2}{*}{$\begin{array}{l}\text { Without } \\
\text { prosthesis } \\
(\mathrm{n}=14)\end{array}$} & \multirow[b]{2}{*}{$\begin{array}{l}\text { Variation } \\
\text { (\%) }\end{array}$} & \multirow{2}{*}{$\begin{array}{c}\text { Difference } \\
\text { between sides } \\
\text { (with prosthesis - } \\
\text { without prosthesis) } \dagger\end{array}$} & \multicolumn{2}{|c|}{ Control group (C) } \\
\hline & & & & & $\begin{array}{c}\text { Left } \\
\text { side } \\
(n=4)\end{array}$ & $\begin{array}{l}\text { Right } \\
\text { side } \\
(n=4)\end{array}$ \\
\hline A & 0,15 & 0,16 & & $-0,01$ & 0,26 & 0,11 \\
\hline A & 0,14 & 0,15 & & $-0,01$ & 0,17 & 0,21 \\
\hline A & 0,13 & 0,17 & & $-0,04$ & 0,11 & 0,10 \\
\hline A & 0,16 & 0,14 & & 0,02 & 0,18 & 0,18 \\
\hline A & 0,14 & 0,17 & & $-0,03$ & & \\
\hline A & 0,30 & 0,14 & & 0,16 & & \\
\hline A & 0,16 & 0,21 & & $-0,05$ & & \\
\hline B & 0,12 & 0,10 & & 0,02 & & \\
\hline B & 0,11 & 0,18 & & $-0,07$ & & \\
\hline B & 0,12 & 0,10 & & 0,02 & & \\
\hline B & 0,12 & 0,16 & & $-0,04$ & & \\
\hline B & 0,12 & 0,13 & & $-0,01$ & & \\
\hline B & 0,14 & 0,21 & & $-0,07$ & & \\
\hline B & 0,11 & 0,16 & & $-0,05$ & & \\
\hline Average & 0,14 & 0,16 & $-7,3$ & $-0,011^{*}$ & & \\
\hline
\end{tabular}

†Student's $t$ test $(p=0,476)$

* Significant at the level of significance $\alpha=0,05$

TABLE 6 - Distribution of the measurements $(\mu)$ of the diameters of the lumen of the seminiferous tubes, according to the side with prosthesis, without prosthesis and control group.

\begin{tabular}{|c|c|c|c|c|c|c|}
\hline \multirow[b]{2}{*}{ Group } & \multirow{2}{*}{$\begin{array}{l}\text { With } \\
\text { prosthesis } \\
(n=14)\end{array}$} & \multirow{2}{*}{$\begin{array}{l}\text { Without } \\
\text { prosthesis } \\
(\mathrm{n}=14)\end{array}$} & \multirow[b]{2}{*}{$\begin{array}{l}\text { Variation } \\
\text { (\%) }\end{array}$} & \multirow{2}{*}{$\begin{array}{c}\text { Difference } \\
\text { between sides } \\
\text { (with prosthesis - } \\
\text { without prosthesis) } \dagger\end{array}$} & \multicolumn{2}{|c|}{ Control group (C) } \\
\hline & & & & & $\begin{array}{l}\text { Left } \\
\text { side } \\
(n=4)\end{array}$ & $\begin{array}{l}\text { Right } \\
\text { side } \\
(n=4)\end{array}$ \\
\hline A & 90 & 91 & & 1 & 87 & 80 \\
\hline A & 60 & 83 & & -23 & 89 & 81 \\
\hline A & 73 & 78 & & -5 & 66 & 77 \\
\hline A & 78 & 75 & & 3 & 69 & 75 \\
\hline A & 83 & 99 & & -16 & & \\
\hline A & 69 & 107 & & -38 & & \\
\hline A & 105 & 78 & & 27 & & \\
\hline B & 66 & 68 & & -2 & & \\
\hline B & 66 & 69 & & -3 & & \\
\hline B & 79 & 75 & & 4 & & \\
\hline B & 74 & 51 & & 23 & & \\
\hline B & 66 & 68 & & -2 & & \\
\hline B & 96 & 62 & & 34 & & \\
\hline B & 78 & 63 & & 15 & & \\
\hline Average & 77 & 76 & 1,5 & $1,1^{*}$ & & \\
\hline
\end{tabular}

†Student's t test $(\mathrm{p}=0,829)$

* Significant at the level of significance $\alpha=0,05$ 


\section{Discussion}

There is a great number of works involving many patients who had undergone prosthetic atensional hernioplasty, especially in the United States of America. They show excellent results with indices of recidivism inferior to $1 \%{ }^{12}$. Like any other surgical procedure, complications are always a surgeon's motive of preoccupation. In the repair of the inguinal hernia, the importance of complications is due not so mush to its frequency or gravity, but to the great number of procedures performed each year ${ }^{13}$. In open surgeries, testicular complications register $0,5 \%$ to $2 \%$ of primary hernias, reaching $55 \%$ of the recurrent hernias ${ }^{14}$. Among the complications of the repair of inguinal hernias is ischemic orchitis that, although rare, is well known because it is a cause of preoccupation and litigation. Tissue reaction on the mesh location, in the long term, may be considered an etiological factor, although its causes are not known. Considering the high incidence of inguinal hernia repairs among male patients examined at infertility clinics, the possibility of involving the spermatic funiculus, due to fibroid reaction, induced by the mesh may be significant. There are a few studies on this subject that analyze these effects $^{2,5}$. We selected the experimental procedure for this study, due to the difficulty to perform prospective clinical studies for this purpose. Dogs are adequate models because their inguinal region is similar to men's, ${ }^{2,17}$. The anesthetic technique proved efficient for this procedure. The surgery was adequately performed. There were neither complications nor mortality. Because of the intimate relationship between the spermatic funiculus and the mesh, adherence between both, as well as between the mesh and the posterior wall of the inguinal canal, found in all the animals, may the considered an expected finding, because the mesh induces an inflammatory reaction causing fibrosis that results in adherence. The association between adherence and inflammatory reaction in the spermatic funiculus was detected in all the animals, including the jeopardizing of the deferent duct. Similar aspects were also found in other studies ${ }^{2,9}$. The presence of inflammatory reaction on the wall of the deferent duct seems to be very important, considering the fact that the deferent duct carries spermatozoids from the epididium to the urethra, on each side of the organism, and any inflammatory lesion or mechanic obtrusion of this structure, on both sides, may cause infertility. The reduction of the lumen of the deferent duct, on the mesh side, could also be caused by the inflammatory process. Corroborating this possibility, is the evidence of a thicker muscular layer on the deferent duct, upstream the mesh contact area (in the median third). On the other hand, because three animals in the control group presented different diameters on the right and left sides, these findings should be cautiously interpreted. The congestion of the pampiniform plexus may be due to the contraction of the mesh. This occurs in the re-creation of the internal orifice of the inguinal canal where the spermatic funiculus is imbedded and surrounded by the mesh opening, possibly causing compression of the structures of the spermatic funiculus. This effect could make the drainage of the venous and lymphatic distal flow difficult at that level of the stricture that includes the testis, causing varicocele $^{2}$. The inflammatory reaction and the reduction of spermatozoids in the epididium seem not to be related to the histological alterations found in the spermatic funiculus and deferent duct, because the dogs in the control group also presented them. Because the chronic inflammatory reaction on the mesh side occurred in the interstice and not in the epididium duct, the possibility of spreading the inflammatory process from the deferent duct seems remote, as mentioned in another study. Therefore, what seems obvious is that the epididium of dogs, especially when they are captured on the streets, might be more sensitive to inflammatory alterations and even infectious alterations, as in the case of a dog in the control group that presented a micro-abscess. Even considering the coherence between the diameters of the lumen of the epididium duct and the deferent duct, it was not possible to assert that there is a relationship with alteration of spermatogenesis, although the only dog that presented it, also presented the same alteration in the deferent duct and in the epididium duct. Spermatogenesis reduction found in the mesh side of a dog, reinforces other studies that call our attention to a possible effect of tissue reaction caused by the mesh that may endanger spermatogenic lineage $\mathrm{e}^{2,5}$. Although this study also observed some alterations found in animals not subjected to any kind of surgical manipulation (control group), the fact that the animals were captured on the streets should be taken into consideration, because their physical condition was not known. The fact that the alterations were prevalent on the structures on the mesh side, signals to the fact that the mesh, when fixed to the posterior wall of the inguinal canal of dogs, is not totally innocuous and, therefore, should be used with caution. Considering the evidence of effects of the synthetic mesh on the structures of the spermatic funiculus and testis, new studies should be conducted, especially because the interest on the association between hernioplasty and infertility has increased in specialized clinics.

\section{Conclusion}

The polypropylene mesh in contact with the spermatic funiculus causes a major inflammatory reaction and a significant reduction in the diameter of the lumen of the deferent duct, as well as a marked reduction in spermatogenesis, in the minority of dogs.

\section{References}

1. Taylor SG, Hair A, Baxter GM, O`Dwyer PJ. Does contraction of mesh following tension free hernioplasty effect testicular or femoral vessel blood flow? Hernia. 2001;5:13-5.

2. Uzzo RG, Lemack GE, Morrissey KP, Goldstein M. The effects of mesh bioprosthesis on the spermatic cord structures: a preliminary report in a canine model. J Urol. 1999;161:1344-9.

3. Di Vita G, Milano S, Patti R, Raimondo D, Di Bella G, D‘Agostino P, Leo P, Cillari E. Cytokine modifications after tension-free hernioplasty or open conventional inguinal hernia repair. Am J Surg. 2001;181:487-91. 
4. Eubanks S. Hérnias. In: Sabiston DC. Tratado de cirurgia: as bases biológicas da prática cirúrgica moderna. $15 \mathrm{ed}$. Rio de Janeiro: Guanabara Koogan; 1999. p.1130-47.

5. Goldenberg A, Matone J, Marcondes W, Focchi G. Efeitos da tela de polipropileno no testículo, epidídimo e ducto deferente de cães. Acta Cir Bras. [serial online] Out-Dez 2001; 16(4). Disponível em: URL: http://www.scielo.br/acb

6. Yavetz H, Harash B, Yogev L, Hoimmonai ZT, Paz G. Fertility of men following inguinal hernia repair. Andrologia. 1991;23:443-6.

7. Wantz GE. Testicular atrophy as a risk of inguinal hernioplasty. Surg Gynecol Obstet. 1982;154:570-1.

8. Michalany J. Técnica histológica em anatomia patológica. 3ed. São Paulo: Michalany; 1998.

9. Fitzgibbons RJ, Salermo GM, Filipi CJ, Hunter WJ, Watson P. A laparoscopic intraperitoneal onlay mesh technique for the repair of an indirect inguinal hernia. Ann Surg. 1994;219(2):144-56.

10. Bussab WO, Morettin PA. Estatística básica. 5ed. São Paulo: Saraiva; 2002.

11. Sprent P. Applied nonparametric statistical methods. 2ed. New York: Chapman \& Hall; 1993.
12. Strassmann V, Santoro S, Malzoni CE, Velhote MCP, Macedo M, Posso IP. Avaliação da hernioplastia protética atensional no tratamento das hérnias inguinais. Rev Col Bras Cir. 1998;25(3):155-60.

13. Schumpelick V, Treutner KH, Arlt G. Inguinal hernia repair in adults. Lancet. 1994;344:375-9.

14. Arvidsson D, Smedberg S. Laparoscopic compared with open hernia surgery: complications, recurrences and current trends. Eur J Surg. 2000;585(suppl):40-7.

15. Akbulut G, Serteser M, Yücel A, Degirmenci B, Yilmaz S, Polat C, San O, Dilek ON. Can laparoscopic hernia repair alter function and volume of testis? Surg Laparosc Endosc Percutan Tech. 2003;13:377-81.

16. LeBlanc KA, Booth WV, Whitaker JM, Baker D. In vivo study of meshes implanted over the inguinal ring and external iliac vessels in uncastraded pigs. Surg Endosc. 1998;12:247-51.

17. Melo RS. Efeitos da prótese de polipropileno colocada por inguinotomia no espaço pré-peritoneal, em cães: avaliação laparoscópica e microscópica [Tese]. São Paulo: Universidade Federal de São Paulo; 2002.

18. Snell RS. Aparelho reprodutor masculino. In: Snell RS (editor) Histologia clínica. 1ed. Rio de Janeiro: Interamericana; 1985. p.443-68.

\section{Correspondence:}

Joaquim Ferreira de Paula

Rua dos Gaviões, 162

27600-000 Valença-RJ

Phones: (55 24)2452-1560 / 8111-9285

joaquimf.depaula@uol.com.br
Conflict of interest: none Financial source: none

Received: May 17, 2005

Review: June 21, 2005

Accepted: July 22, 2005

\section{How to cite this article:}

Goldenberg A, Paula JF. Effects of the polypropylene mesh implanted through inguinotomy in the spermatic funiculus, epididium and testis of dogs. Acta Cir Bras. [serial on the Internet] 2005 Nov-Dec;20(6). Available from URL: http://www.scielo.br/acb

*Color figures available from www.scielo.br/acb

\section{AVISO AOS AUTORES}

\section{Solicita-se aos autores observarem o estilo e as Normas da Revista Acta Cirúrrgica Brasileira.}

Consultar os artigos publicados em fascículos recentes da revista.

Acessar http://www.scielo.br/acb - Instruções aos autores.

Informações adicionais pelo e-mail: sgolden@terra.com.br 